\title{
Financial Inclusion In Zimbabwe: A Contextual Overview
}

\section{Sibert Chitokwindo}

Agricultural Banking Corporation(Agribank), Hurudza House, 5680 Hughes St P.O. Box 211, Masvingo, Zimbabwe

\section{Stephen Mago(PhD)}

University of Fort Hare, P.O Bo X1314, Alice, 5700, South Africa

Email: stepmago@gmail.com

\section{Costa Hofisi(PhD)}

North-West University, Faculty of Commerce \& Administration, School of Management Sciences, Private BagX2046 Mmabatho,2735. South Africa

\section{Doi:10.5901/mjss.2014.v5n20p415}

\begin{abstract}
The purpose of this article is to give an overview of financial inclusion in Zimbabwe. Financial inclusion is an important and contemporary aspect the world over. In Zimbabwe, many people are excluded from the financial sector and this has created high levels of poverty and inequality in the country. The article follows a qualitative research methodology. The overview is done using existing literature, driven by an exploratory approach. The results show that financial exclusion comes in different forms and it is responsible for poverty and inequality in Zimbabwe. Most of the 'unbanked' dwell in the rural areas hence the need for developing the rural banking sector for local resource mobilisation and business development. The majority(about $65 \%$ ) of the people dwell in the rural areas. The rural dwellers are excluded from the financial mainstream and do not have good access to financial resources. Consequently, they remain on the lowest rung of the development ladder. The development of rural banks has potential to develop rural businesses that are currently underdeveloped partly because of lack of financial resources. Financial inclusion will promote local savings and investments thus developing rural businesses.
\end{abstract}

Keywords: Financial resources, 'Unbanked', resource mobilisation, business development, Financial exclusion, inequality, Zimbabwe.

\section{Introduction and Background}

Sixty five percent (65\%) of the Zimbabwean population live in the rural areas while $35 \%$ live in the urban area (Zimstat 2012). The age distribution shows that $40 \%$ are aged between 18 and 30 years whilst $48 \%$ of the population is in the 31 60 years age group and $12 \%$ are over 60 years (Zimstatt 2012). The majority of the people are in the economically active range of $18-60$ years and in need of financial services. The country is grappling to recover from the effects of ten years of recession, 1998 to 2008 (dubbed the lost decade), which led to abandonment of the local currency and adoption of a multicurrency regime in February 2009.

The year 1997 marked the beginning of Zimbabwe's economic down turn as aptly put by Kanyenze et al (2011: 483) that "the economic problems afflicting Zimbabwe arguably began in the last quarter of 1997 and reached a crescendo in 2008." There were two developments that culminated in the infamous plunge of the country's currency on 14 November 1997 which became known as the "Black Friday". Bond and Manyanya (2003:38) put forward that; "the precise moment that the Zimbabwean economy began its generalised plunge was probably the late morning of 14 November 1997, when over a four-hour period, the Zimbabwe dollar lost 74\% of its value." First, the crisis was attributed to the $Z \$ 50000$ once off gratuity payment to each of the more than 50000 war veterans plus $Z \$ 2000$ monthly pension for each war veteran thereafter. This was unbudgeted money. Second, Government began to implement the Land Designation Act and 1500 white owned farms were identified for redistribution, resulting with the International Monetary Fund and the World Bank withdrawing balance of payment support (Bond and Manyanya 2003). The sudden fall of the Zimbabwean dollar against the major currencies caused price increases and the Government introduced price controls on most basic goods and this resulted in a general shortage of these goods on the market as business considered the gazetted prices unviable. What followed were food riots and workers' stay-away protests led by the Zimbabwe Congress 
of Trade Unions (ZCTU) on 9 December 1997 dubbed "the Red Tuesday" (Bond and Manyanya 2003). That marked the beginning of a decade of economic hardships spurred by hyperinflation whose official publication ended on 31 July 2008 when the rate of inflation was at 230000 000\% (Reserve Bank of Zimbabwe-RBZ 2009, IMF 2009, Indexmundi 2010 and Makina 2010). The economy registered negative GDP and was forced to adopt multicurrency system to bring stability into the economy (Chikoko 2014).

The adoption of the multicurrency system resulted in the turnaround of the economy as reflected by price stability, single digit inflation rate and GDP growth. Following a decade of economic decline, the economy recorded a real GDP growth of 5.9\% in 2010 (Zengeni 2012). The priority sectors that are targeted at turning around the economy are Agriculture, Mining, Manufacturing and Tourism. The adoption of the multicurrency system and the Global Political Agreement, where the three main political parties worked together in an inclusive Government, stabilized the economy which was slowly recovering though under political uncertainty. The RBZ (2011:15) comments that "economic performance is, however, still constrained by challenges that include power outages, liquidity shortages, obsolete infrastructure, external debt overhang, low aggregate demand, skills gap and high unemployment". These constraints bite more on the low income earners whose families are normally dispersed with the father based in the urban area trying to earn a living whilst the rest of the family is in the rural areas. The less fortunate ones are those families who are peasant farmers and rely on income from selling farm produce that often comes once in a year, if at all. Peasant farmers often rely on occasional funds from relatives and friends sent through bus drivers or other people. Thanks to electronic money transfer facilities that have picked the slack. These include Econet's Ecocash, Telecel's Telecash among other facilities. The rural road network is in poor state especially due to lack of maintenance. The situation is worse in the resettlement areas where no roads existed when people where resettled. No roads have been constructed since people were resettled. The areas have remained inaccessible and people walk long distances to the nearest road. By the year 2007, a total of 244 commercial farms in Masvingo Province had been acquired for resettlement purposes under the A1 model (subsistence farming) with a combined hectarage of 1195564 and a carrying capacity of 33197 families. The Postal system that used to assist the rural folks to send and receive money to relatives and friends is no longer reliable.

\section{The Zimbabwean Financial Services Sector}

At independence in 1980, the Government inherited the best banking systems in Africa outside South Africa, at a time when the majority black population had a strong sense of having been excluded from access to modern services, including credit (Brownbridge and Harvey 1998). The country deregulated the banking sector in the early 1990s which resulted in black owned banking institutions coming up to compete with the traditional institutions (Kanyenze et al 2011). However, the competition was mainly concentrated in Merchant banking where a number of experienced indigenous bankers pooled resources and opened banks which included National Merchant bank(NMB), Trust Merchant bank(TMB), Universal Merchant bank(UMB) and United Merchant bank(UNB). The First Banking Corporation(FBC) was the first indigenous commercial bank to be licenced in 1997 to bring the number of commercial banks to six from the traditional five banks, Barclays, Standard Chartered, Zimbank, ANZ Grindlays (now Stanbic) and The Bank of Credit and Commerce International (now Commercial Bank of Zimbabwe-CBZ) (RBZ 2012).

The banking sector was not spared by the economic meltdown that crystallized in late 1997. During 2004, some commercial banks (for example Trust bank, Royal bank, Time bank and Barbican bank) were placed under curatorship and their banking licences withdrawn by the RBZ despite efforts by the central bank to set up a Troubled Bank Fund (TBF) to try and save banks whose collapse was imminent (RBZ 2004). Eventually the RBZ had to create a special purpose vehicle, Allied Financial Services from assets of the troubled banks. The RBZ (2004:55) posits that,

"The Reserve bank created a Special Purpose Vehicle (SPV), Allied Financial Services (Pvt) Ltd, which facilitated the conversion of debt in troubled banks into equity. Troubled banking institutions that qualified were then consolidated into a single entity known as Zimbabwe Allied Banking Group (ZABG), which was granted a banking licence and commenced business on 31 January 2005"

The three banks that were amalgamated into ZABG were Trust bank, Royal bank and Barbican bank. Depositors lost their money from these collapsed institutions although their deposits were converted into equity in the ZABG, hyperinflation had eroded the value by the time the funds became accessible.

As the economy continued to plunge, banks were reeling to maintain viability and branch closure was an option to many banks that had expanded into rural areas. Kanyenze et al (2011:485) posit that "a combination of branch closures and the persistent rigid monetary policy that set unrealistic maximum daily withdrawal limits encouraged people to 
transact outside the banking system, thereby furthering financial exclusion. As a result, by 2007, only $18.3 \%$ of the population had access to a bank account". Depositors further lost their funds when the country adopted the multicurrency system in February 2009 when banks hived the Zimbabwean dollar balances awaiting policy position from the Central bank on how to compensate the depositors. The Central bank did not issue a policy position regarding the fate of the Zimbabwean dollar balances, thus people generally lost confidence in the Zimbabwean banking system. The current liquidity challenges that the country is facing is attributed, to some extent, to the loss of confidence in the banking system by business and individuals who are circulating cash outside the banking system in fear of the financial demise they faced when they lost their Zimbabwe dollar funds.

Table 1: Structure of the Zimbabwe Banking Sector

\begin{tabular}{|l|c|}
\hline Type of Institution & Number \\
\hline Commercial Banks & 18 \\
\hline Merchant Banks & 2 \\
\hline Building Societies & 4 \\
\hline Savings Bank & 1 \\
\hline Finance Houses & 0 \\
\hline Discount Houses & 0 \\
\hline Total Banking Institutions & $\mathbf{2 5}$ \\
\hline Asset Management Companies & 16 \\
\hline Microfinance Institutions & 172 \\
\hline
\end{tabular}

Source: RBZ (2012:25)

Zimbabwe has been facing liquidity challenges since the adoption of the multicurrency system in 2009. According to the RBZ (2012:22) "it is noteworthy that, under the auspices of a multicurrency regime, where the Reserve Bank does not issue currency, liquidity sources are limited". The banking sector deposits amounted to US $\$ 4,02$ billion as of July 2012 and the deposits growth had drastically slowed to 16\% from 56\% during the same period in 2011 (RBZ 2012). Since the dollarization programme, the Zimbabwean economy shown an insatiable demand for imports. Consequently, it continued to experience a ccurrent account deficit due to the net outflow of foreign exchange. Thus, the liquidity situation in the banking sector was worsened. Economic growth is therefore stifled due to limited capacity by banks to finance industry requirements. The resultant effect is the growth of unemployment and the marginalization of the poor, thus financial exclusion becomes inevitable.

\section{Financial Inclusion in Zimbabwe}

The RBZ came up with a framework for financial inclusion in 2007 which was premised on the following pillars:

- expanding the outreach of established developmental financial institutions such as People's Own Savings bank (POSB), ZIMPOST and Agribank;

- expanding the outreach of established commercial banks and building societies;

- enhancing provision of microfinance services through establishment of microfinance banks (MFI Banks) or Financial Inclusion Centres (FICs);

- urging relevant authorities to ensure provision of adequate infrastructure including roads, telecommunication coverage and provision of electricity;

- provision of appropriate incentives to financial institutions engaged in rural banking; and

- engaging other stakeholders to facilitate the provision of other incentives.

Source: RBZ (2006:56)

The approach puts emphasis on the banks setting up delivery channels in the rural areas which in itself would take time to achieve and also could go the Indian way where establishment of many rural bank branch networks did not really result in financial inclusion. Regrettably, the Government of Zimbabwe is currently focused on the conventional way of financial inclusion through pursuing expansion of financial institutions' network in the rural areas. The Government of Zimbabwe, cognizant of the marginalization of the low income earners from the mainstream economy, will employ a strategy to 
promote financial inclusion through the creation of more financial institutions that include microfinance banks and leasing companies (Ministry of Finance 2011). The RBZ (2011:32) weighed in by "encouraging banks to extend provision of financial services to the marginalized poor and rural communities who are 'unbanked' to enable them to make a meaningful contribution to the economy". However, much as the RBZ may want banks to expand into the rural areas, there are viability considerations to be made as clearly put by Mahmood and Sahai (2011:203) "for any model to be selfsustaining and successful in the long run, concerns for both sides have to be addressed. From the banker's point of view, the issue is that of viability and, after that profitability." The call by the RBZ has all along been that of moral suasion and in the absence of supportive legislation, the brick and mortar approach may not necessarily deliver the required results as much will depend on whether banks will consider the rural bank concept viable and profitable. No wonder this has taken long for some of the banks to set up branches in rural areas. Other banks have actually closed rural branches citing viability challenges.

According to FinMark (2012), 38\% (2 316 877) adult Zimbabweans are formally served, however, $40 \%$ are financially excluded in that they do not have/use financial products/or services. If borrowing they rely on friends/family; and when saving they save at home. $41 \%$ are financially included but they are informally served and use co-operatives, farmer associations, savings clubs/groups and private money lenders. $24 \%$ are banked and $26 \%$ use other formal bank products/services. $51 \%$ of rural adults are financially excluded whilst $27 \%$ rural adults use informal products/services. The statistics show that the rural people are to a larger extent financially excluded.

Figure 5: Financial Inclusion Overview [The figures are in percentages]

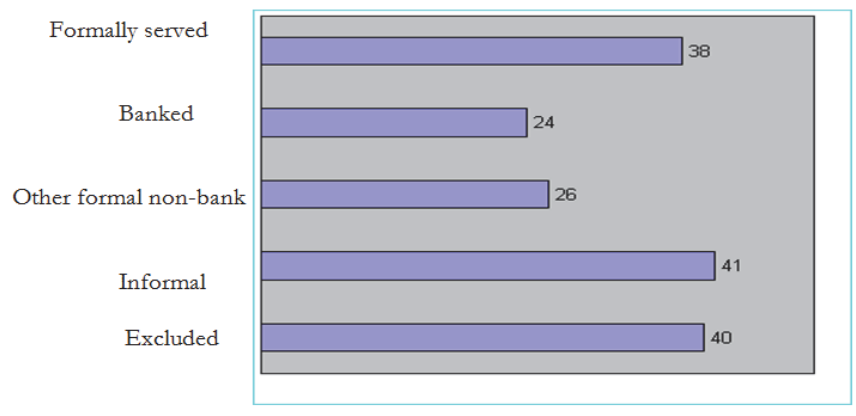

Source: FinMark Trust (2012:19)

\section{Banking Industry}

The banking sector has 21 operating banks, including the People's Own Savings Bank and 146 microfinance institutions (POSB) (RBZ, 2014). Contribution to total bank assets are $82.69 \%$ by commercial banks, $1.35 \%$ by savings bank, $13.65 \%$ by Building Societies and $2.31 \%$ by Merchant banks (RBZ 2014). The country adopted a multicurrency system in February 2009 and since then, banks have been operating with price structures that the RBZ view as not affordable to the poor people. The RBZ (2011:19) stated that

"the pricing, terms and conditions of financial products (including interest charges, all fees and etc) should be transparent and be adequately disclosed in a form understandable to clients. Responsible pricing means that pricing, terms, and conditions are set in a way that is both affordable to clients and sustainable for microfinance institutions".

Deposit mobilization in the sector has been observed as being stifled by the informal sector whose transactions the banking sector has failed to capture. It is believed that $\$ 2$ billion is circulating in the informal sector and this money never finds its way into the formal banking sector (RBZ 2011). There are various reasons why the informal sector and the low income earners do not operate bank accounts. The banking sector is mainly driven by transactional and saving products at $10 \%$ and $17 \%$ respectively. $5 \%$ use banks for remittances whilst $3 \%$ use it for credit products (FinMark 2012). The statistics clearly reflect the need for banks to attract people to demand their products through making them affordable and accessible by the majority of people. 


\subsection{Bank Business Conditions}

The cost of maintaining a bank account has been cited as prohibitive especially to the low income people. There is a monthly ledger fee collected from accounts and a transaction fee is levied on most of the transactions. Business conditions relating to current and savings accounts slightly differ from one bank to the other as reflected in the diagram below:

Table 2: Bank Charges As At 30 June 2011

\begin{tabular}{|l|c|c|c|c|}
\hline Category of Service & \multicolumn{2}{|c|}{ Minimum } & \multicolumn{2}{c|}{ Maximum } \\
\hline Cash withdrawal & $0.10 \%$ & $\$ 1.00$ & $1.50 \%$ & $\$ 25.00$ \\
\hline ATM withdrawal & $0.35 \%$ & $\$ 1.00$ & $1.00 \%$ & $\$ 25.00$ \\
\hline Cheque book fee (per 25 leaf book) & - & $\$ 4.00$ & - & $\$ 11.50$ \\
\hline Inter Account transfer & - & $\$ 0.50$ & - & $\$ 2.00$ \\
\hline Ledger fees & $0.10 \%$ & $\$ 1.00$ & $0.30 \%$ & $\$ 250.00$ \\
\hline Monthly administration fee & - & $\$ 0.00$ & - & $\$ 40.00$ \\
\hline RTGS & $0.05 \%$ & $\$ 1.00$ & $0.50 \%$ & $\$ 20.00$ \\
\hline Certificate of balance & - & $\$ 0.50$ & - & $\$ 5.00$ \\
\hline
\end{tabular}

Source: RBZ (July 2011:31)

The RBZ considers the bank charges as high and discourages use of the formal banking channels and is urging banks to review their costs structures and pricing policies in a sustainable way. It also supported the low cost products and services like plastic money and mobile products. However, the RBZ has no supporting legislation to enforce these measures and only uses persuasion. Besides charges being a barrier to the low income earners accessing financial services, the institutions themselves are not easily accessible especially in the rural areas where the majority of people live.

\subsection{Geographical Spread of Banks}

Most banks are represented in urban centres whilst only POSB, Agribank and CBZ bank have a strong rural presence despite the call since 2006 by the RBZ for banks to open branches in rural areas. According to FinMark (2012:25), "only $5 \%$ of Zimbabweans in rural areas have access to a bank (within 30 minutes reach)". Therefore, banks need not only review costs in terms of charges, but reduce travelling costs for the customer by bringing services as close as possible to the 'unbanked' communities.

Table 3: Bank Branch Network in 2006

\begin{tabular}{|c|c|c|c|c|c|c|c|c|}
\hline Province & $\begin{array}{c}\text { Total branch } \\
\text { network }\end{array}$ & $\begin{array}{l}\% \text { of total } \\
\text { branches }\end{array}$ & $\begin{array}{l}\text { Urban } \\
\text { pop }\end{array}$ & $\begin{array}{c}\text { Urban } \\
\text { branches }\end{array}$ & $\begin{array}{c}\text { Urban population } \\
\text { per branch }\end{array}$ & $\begin{array}{c}\text { Rural } \\
\text { population }\end{array}$ & $\begin{array}{l}\text { Rural branch } \\
\text { facilities }\end{array}$ & $\begin{array}{c}\text { Rural population } \\
\text { per branch }\end{array}$ \\
\hline Harare & 148 & $39 \%$ & $1,896,134$ & 148 & 12,812 & - & 0 & - \\
\hline Bulawayo & 51 & $14 \%$ & 696,650 & 51 & 13,268 & - & 0 & - \\
\hline Midlands & 39 & $10 \%$ & 349,595 & 28 & 12,486 & $1,914,398$ & 11 & 101,309 \\
\hline Mashonaland east & 15 & $4 \%$ & 117,521 & 11 & 10,684 & $1,009,892$ & 4 & 252,473 \\
\hline Mashonaland west & 32 & $8 \%$ & 344,806 & 28 & 12,315 & 79,864 & 4 & 219,966 \\
\hline Mashonaland central & 12 & $3 \%$ & 102,873 & 6 & 17,146 & 892,554 & 6 & 148,759 \\
\hline Matebeleland north & 13 & $3 \%$ & 102,948 & 11 & 9,359 & 602,000 & 2 & 301,000 \\
\hline Matebeleland south & 9 & $2 \%$ & 68,457 & 5 & 13,691 & 584,597 & 4 & 146,149 \\
\hline Masvingo & 22 & $6 \%$ & 134,251 & 19 & 7,066 & $1,186,187$ & 3 & 395,396 \\
\hline Manicaland & 36 & $10 \%$ & 259,495 & 26 & 9,981 & $1,309,435$ & 10 & 130,944 \\
\hline Total & 377 & $100 \%$ & $4,052,730$ & 333 & & $7,578,927$ & 44 & \\
\hline
\end{tabular}

Source: RBZ (2007:6)

The above table provides a clear picture of how the rural people are deprived of financial services. Technological development has potential to close this gap if adopted early and expansively. 


\subsection{Financial Services Sought}

There are five financial services sought by adult Zimbabweans which are Transactional, Savings, Credit, Insurance and Remittances. According to FinMark (2012), 37\% of the people in Zimbabwe save but mainly at home or with savings clubs whilst only $11 \%$ save through the formal banks. $28 \%$ use transactional products through banking halls, ATMs or cash point cards. $31 \%$ use Insurance products which include pension, medical and funeral cover. FinMark further states that $20 \%$ use credit products with the use more common in rural areas although the majority rely on borrowing from friends and family. Only $18 \%$ use remittance either sending or receiving money and is more prevalent in urban areas (FinMark 2012). These figures are total for urban and rural but the rural statistics alone are quite interesting and show high levels of usage although they are mainly in the informal sector. These activities could be incorporated into the formal sector if rural people had access to formal financial services. Rural people resort to using informal sector services because of access barriers in the formal sector.

\subsection{Barriers to Bank Accounts Access}

Barriers to access bank accounts are inaccessibility due to distance, unaffordability to the rural people and low income earners, inappropriacy of products offered, lack of documentation and lack of money. These have been referred to as access exclusion, cost exclusion, condition exclusion, marketing exclusion and self-exclusion (Kempson et al. 1999). Some of the solutions prescribed to overcome these barriers include the call by the RBZ for banks to embrace ICT and innovate to products that reach the low income earners and the poor. Therefore ICT and Telecommunications has a role to play in promoting financial inclusion in Zimbabwe.

\section{Information Communication Technology}

Zimbabwe has ICT challenges due to slow developments in that sector. Usage is beyond the reach of many ordinary Zimbabweans with low and costly broadband penetration (Ministry of Finance, 2011). Access levels of the different modes of communication are as follows; Internet 16\%, Landline at home $5 \%$, Public phone $4 \%$ and Cell phone $85 \%$ (FinMark, 2012). The majority of the people have access to the cell phone and therefore mobile banking has potential to offer better penetration into the financially excluded areas. Zimbabwe has three mobile network providers namely Econet Wireless, NetOne and Telecel. They have a combined potential to give access to financial services to $85 \%$ of the country's population who have access to the cell phone.

\section{Mobile Banking}

Mobile banking initiatives have come from the banks and telecommunications companies and most banks have introduced the mobile banking product. Zimbabwe has no law binding financial institutions to adopt financial inclusion and adoption has come as a result of service providers taking the initiative spurred by competition. The concept is still in its infancy and not all banks are offering the full bouquet of $m$-banking services.

\subsection{Bank Focused Model}

Most banks that have introduced mobile banking have limited the product to SMS banking which offers balance enquiry and transaction alerts. Transactions have largely remained traditional and those that are offered outside banking halls are limited to ATMs and POS only. The bank focused model does not necessarily bring on board those that have been excluded due to price, market and condition barriers. There is no change in business conditions but rather the thrust is on giving convenience to customers who meet the required conditions. The ATMs and POS machines can only be installed in areas where the bank considers suitable. Unlike in South Africa, where banks have adopted the branchless banking model and put ATMs in areas where building brick and mortar structures have been considered unviable, no such initiative has taken place in Zimbabwe. ATMs and the branch are inseparable or in close proximity. The primary motive is to decongest banking halls and also to afford customers unlimited access to their accounts. Thus banks remain channels for the chosen few and not for the majority of low income earners. 


\section{Bank Led Model}

Three banks, ZB bank, FBC bank and Kingdom bank have partnered with mobile phone companies to offer mobile banking with a wider range of services. The facility allows customers to enquire account balance, view account statement, purchase air time, make inter account transfers, and remittances and pay bills. ZB bank is offering the eWallet service through all three cell phone companies. FBC bank has partnered with NetOne to offer One-Wallet whilst Kingdom bank has introduced Skwama with Telecel. The bank and the GSM network provider are linked through a mobile banking platform and the customer must have an account with the bank. Those without bank accounts are automatically excluded which means most of the Bank Led mobile banking products have this limitation serve for Kingdom bank's Cell Card product which is accessible by both bank and non-bank customers.

\subsection{The Cell Card}

Kingdom Cell Card is an integrated mobile payment platform through Cell phone, Point-Of-Sale, Automated Teller Machines, Internet and Debit card. It offers the convenience of doing banking anywhere anytime as long as there is a mobile network, internet connection or a Kingdom service point (Kingdom Bank 2012). The Kingdom cell card allows the sending of money to another cell phone holder for as long as the sender has float cash in his/her cell phone. The float money can be cashed at any cell card agent.

Benefits

- Doing banking anywhere, anytime.

- Very low cost

- Simple to open

- Available on four channels (Cell phone, ATM, Internet and POS)

Products And Services

- Send money

- Receive money

- Balance Inquiry

- Airtime Top Up

- Purchase

- Cash withdrawal

- Cash Deposit

- Funds Transfers \&Money Transfer Claim

- SMS Alerts

- Bill Payments

- Bank Statements

- Cardless ATM withdrawal

Source: http://www.kingdom.co.zw/virtual_banking(2012)

The Cell card has easy requirements and only requires one to have a national Identity card and cell phone. Opening of the account takes a matter of minutes with a minimum deposit of US $\$ 1.00$ and the account can be opened through an air time vendor, agent or at any of the bank's branches.

\subsection{Non-Bank Led Model}

The non-bank led mobile banking product is where a telecommunication company offers mobile banking services that are not directly linked to a bank. In Zimbabwe this has been pioneered by Econet Wireless through the Ecocash product. It is modelled along the M-PESA(Wambari 2009, Mbiti 2012) m-banking facility of Kenya.

\subsection{The EcoCash Product}

Econet Cellular introduced the EcoCash product in September 2011. The facility allows money transfers across the three 
cellular networks, thus giving everyone with access to a cell phone an opportunity to use the product (Econet, 2014). EcoCash allows people to send and receive money quickly and easily from cell phone to cell phone and it is considered safe (Techzim 2012). The sender of money transfers cash into the EcoCash Wallet dubbed "float money" which one can use to purchase airtime, pay bills, transfers to another person or redeem float money back to cash. The EcoCash product is growing very fast and had registered users numbering 1,7 million in just one year (Techzim 2012). EcoCash has potential to perform like the M-PESA of Kenya that registered 9 million customers in three years (Wambari 2009, Mas and Radcliffe 2010).

\section{Mobile Banking Tariffs}

Banks have different cost structures that they levy for m-banking transactions. The Skwama product charges are between $\$ 0.03$ and $\$ 1.00$ depending on the nature of the transaction (Telecel 2013). FBC bank charges up to $\$ 10$ as shown in the table below.

Table 4: One Wallet Charges

\begin{tabular}{|l|c|}
\hline Activity & Charges \\
\hline Pay in Cash $(\$ 5-\$ 50)$ & 0 \\
\hline Sending money $(\$ 5-\$ 500)$ & $1.5 \%$ of transaction value \\
\hline Withdrawing cash $(\$ 5-\$ 500)$ & $2 \%$ of transaction value \\
\hline Bill payments & $\$ 0.20$ \\
\hline Balance enquiry & $\$ 0.05$ \\
\hline Last transaction & $\$ 0.05$ \\
\hline Airtime top up & Free \\
\hline Bank to One Wallet & Free \\
\hline
\end{tabular}

Source: onewallet@netone.co.zw

Ecocash transactions attract a 5\% minimum charge which is levied when the transaction involves registered sender and receiver. However, when the receiver is not registered, the tariff is $7 \%$ divided into $3 \%$ charged to the sender and $4 \%$ charged to the receiver (Econet 2014). Unlike banks, maintaining the Ecocash membership does not attract monthly fees and membership does not expire.

\section{Conclusion}

The importance of financial inclusion can never be over emphasized. The paper has indicated that mobile banking has come as a catalyst for financial inclusion, business development and poverty reduction. Most of the people in the rural areas do not have bank accounts, hence they are excluded from the formal financial mainstream. The cellphone revolution in Zimbabwe and other developing countries is closing the gap through the promotion of financial inclusion. Products such as Ecocash, NetCash and Telecash are improving the access of financial services to the previously marginalised groups. They are very handy in effecting money and remittance transfers. Costs of doing business have also plummeted due to the innovative and technologically enhanced money transfer services. Moreover, the development of rural banks has potential to develop rural businesses that are currently underdeveloped, partly because of lack of financial resources. Financial inclusion promotes local savings and investments, thus developing rural businesses and reducing poverty among marginalised groups.

\section{References}

Bond, P. and Manyanya, M. (2003). Zimbabwe's Plunge: Exhausted Nationalism, Neoliberalism and Search for Social Justice, Weaver Press, Harare.

Brownbridge, M, and Harvey, C. (1998). Banking in Africa: The Impact of Financial Sector Reform Since Independence. Africa World Press, USA.

Chikoko L. (2014). Potential Sources of Zimbabwe Commercial Banks Illiquidity after Dollarisation. Journal of Contemporary Issues in Business Research. Vol.3, No.1, 41-51.

Econet (2012). http:/www.econet.co.zw 
FinMark (2012). FinScope Consumer Survey Zimbabwe 2011.www.zimstast.co.zw/dmdocument/Finance/Launch.pdf IMF. (2009). Zimbabwe: IMF Country Report No. 09/139. Washington D.C.

Indexmundi. 2010. Zimbabwe Unemployment and Inflation Rates. http://www.indexmundi.com/zimbabwe/unemployment_ rate.html.(accessed 4 July 2010).

Kanyenze, G., Kondo, T., Chitambira, P., and Martens, J. (2011). Beyond the Enclave,

Towards a Pro-Poor and Inclusive Development Strategy for Zimbabwe.Weaver Press, Harare.

Kempson, E., Atkinson, A. and Pilley, O. (2004). Policy Level Response to Financial Inclusion In Developed Economies: Lessons For Developing Countries, University of Bristol.

Kingdom Bank(2012). Virtual Banking. [Online] Available: http://www.kingdom.co.zw/virtual_banking (August 5, 2014).

Mahmood, I. and Sahai, S. (2011). Profitable Models for Financial Inclusion, State Bank Staff College.

Makina, D. (2010). Historical Perspectives on Zimbabwe's Economic Performance: A Tale of Five Lost Decades. Journal of Developing Societies (2010) 26:99-123. Washington D.C: SAGE Publications.

Mas, I. and Radcliffe, D. (2010). Mobile Payments go Viral: M-PESA in Kenya.

Bill and Melinda Gates Foundation.

Mbiti, I. and Weil, D.N. (2011), Mobile banking: The Impact of M-Pesa In Kenya. [Online\} Available:http:/www.nber.org/papers/w17129. (August 20, 2013).

Ministry of Finance (2011). 2012 Budget Strategy Paper: Building on Our Priorities. Harare, Zimbabwe.

Reserve Bank of Zimbabwe(RBZ). (2004). Monetary Policy Statement.

$$
\text { (2009). Monetary Policy Statement. }
$$

Techzim. (2012). Now 270,000 active EcoCash users, and more than 1.5m registered. [Online] Available:http://www.techzim.co.zw/ 2012/07/now-270000-active-ecocash-users-and- more-than-1-5m-registered/(August 5, 2014).

Telecel (2013). http://www.telecel.co.zw/

Wambari,A. P. M. (2009). Mobile Banking In Developing Countries: A Case for Kenya, Vaasan Ammattikorkeakoulu University of Applied Sciences.

Zengeni, T. K. (2012). Zimbabwe: A country Profile.[Online] Available: http://www.myjurnal.my/filebank/published_article/16209/jis79.pdf (September 12, 2013).

Zimstat. (2012). Zimbabwe Population Census 2012. Harare. [Online] Available: www.zimstat.co.zw/.../Census/CensusResults2012/ National_Report.pdf (August 6, 2014) 